\title{
A karbonilstressz szerepe a diabetes szövődményeinek kialakulásában
}

\author{
Makk-Merczel Kinga ${ }^{1}$. Szarka András dr. ${ }^{1,2}$ \\ ${ }^{1}$ Budapesti Múszaki és Gazdaságtudományi Egyetem, \\ Vegyészmérnöki és Biomérnöki Kar, Alkalmazott Biotechnológia és Élelmiszertudományi Tanszék, \\ Biokémiai és Molekuláris Biológiai Laboratórium, Budapest \\ ${ }^{2}$ Semmelweis Egyetem, Általános Orvostudományi Kar, \\ Orvosi Vegytani Molekuláris Biológiai és Patobiokémiai Intézet, Budapest
}

\begin{abstract}
A 2017-ben mintegy 451 millió, diabetesben szenvedő emberben potenciálisan kialakuló hosszú távú szövődmények és a hyperglykaemia között fennálló kapcsolatot a nagyobb mértékben keletkező késői glikációs végtermékek, valamint a fokozott oxidatív és karbonilstressz jelentheti. A részben karbonilstressz révén keletkező késői glikációs végtermékek szerepét olyan szövődményekben írták le, mint az érfalvastagodás, a megnövekedett érfal-áteresztőképesség, a fokozott mértékú angiogenezis vagy a csökkent érfalrugalmasság okozta nephropathia, neuropathia, retinopathia. A sort folytathatnánk a megnövekedett thrombocytaaggregációval, a csökkent fibrinolízis kiváltotta fokozott koagulációs aktivitással vagy az atherosclerosissal, illetve a mitokondriális diszfunkcióval. Mind az oxidatív, mind a nem oxidatív késői glikációs végtermék képződésének legpotensebb támadási pontja az $\alpha, \beta$-telítetlen aldehidek befogása lehet. Sajnálatos módon a befogó molekulák prototípusát jelentő aminoguanidin, bár különböző állatmodelleken sikeresnek bizonyult, a klinikai teszteken nem bizonyított, a vele kapcsolatos klinikai vizsgálatokat közel 20 évvel ezelőtt leállították. Az aminoguanidin mellett nagy várakozás övezte az endogén dipeptid L-karnozint, amely szintén hatásosan csökkenti a karbonilstresszt. Ez esetben a humán alkalmazást az emberekben jelen lévő specifikus szérumkarnozinázok, az alacsony szérumstabilitás és a biológiai hasznosulás limitálta. A múlt év végén a molekula karboxilcsoportjának hidroxilcsoportra történő cseréjével sikerült elérni, hogy ellenálló legyen a karnozinázoknak, ugyanakkor megőrizze biológiai biztonságát és karbonilstresszt csökkentő hatását. Bár a karnozinol kifejlesztése óta eltelt mindössze fél év nem tette lehetôvé, hogy klinikai teszteken bizonyítson, a molekulával kapcsolatban elért in vitro és in vivo eredmények alapján ígéretes hatóanyagnak tűnik a diabetes szövődményeinek mérséklésére, megelőzésére, így a klinikusnak is érdemes nyomon követni a vele kapcsolatos híreket, eredményeket.
\end{abstract}

Orv Hetil. 2019; 160(40): 1567-1573.

Kulcsszavak: diabetes, szövődmények, oxidatív stressz, karbonilstressz, karnozinol

\section{The role of carbonyl stress in the development of diabetic complications}

The relationship between the potentially developing complications of the 451 million people affected by diabetes and hyperglycaemia can be based on the enhanced generation of advanced glycation endproducts and the more intensive oxidative and carbonyl stress. Advanced glycation endproducts generated partly due to carbonyl stress play an important role in the pathogenesis of diabetic complications such as elevated arterial thickness, vascular permeability, enhanced angiogenesis or the more rigid vessels induced nephropathy, neuropathy, retinopathy. Furthermore, the elevated thrombocyte aggregation, the reduced fibrinolysis induced elevated coagulation, and the atherosclerosis or the mitochondrial dysfunction are important as well. The most potent target of both the non-oxidative and oxidative generation of advanced glycation endproducts can be the scavenging of $\alpha, \beta$-unsaturated aldehydes. Although, aminoguanidine, the prototype of scavenger molecules, showed protection in different animal models, it failed in the human clinical studies. Finally, the clinical studies were terminated almost 20 years ago. The endogen dipeptide L-carnosine was also expected to mitigate the complications due to carbonyl stress. However, its clinical significance was limited by the serum carnosinases and by the consequent low serum stability and bioavailability. The carnosinase resistance of the molecule can be achieved by the change of the carboxyl group of the molecule to hydroxyl group. At the same time, the biosafety and the carbonyl stress scavenging activity of the molecule could be preserved. Although clinical studies could not be performed in the last six months, on the basis of the in vitro and in vivo results, carnosinole seems to be a promising compound to mitigate and prevent the diabetic complications. Thus it is worth to the attention of the clinicians. 
Keywords: diabetes, complications, oxidative stress, carbonyl stress, carnosinole

Makk-Merczel K, Szarka A. [The role of carbonyl stress in the development of diabetic complications]. Orv Hetil. 2019; 160(40): 1567-1573.

(Beérkezett: 2019. április 29.; elfogadva: 2019. június 1.)

\begin{abstract}
Rövidítések
3-DG = 3-deoxiglukozon; 4-HNE = 4-hidroxinonenál; AGE = (advanced glycation endproduct) késői glikációs végtermék; AGERl = (advanced glycation endproduct receptor l) késôi glikációs végtermék 1 -es receptora; $\mathrm{ATP}=$ (adenosine triphosphate) adenozin-trifoszfát; $\mathrm{BME}=$ Budapesti Múszaki és Gazdaságtudományi Egyetem; CML $=\left(\mathrm{N}^{\varepsilon-}[\right.$ carboxymethyl $]-$ lysine) $\mathrm{N}^{\varepsilon}$-[karboximetil]-lizin; CNDP-1 és -2 = karnozin-dipeptidáz-1 és -2 izoformákat kódoló gének; EMMI = Emberi Eróforrások Minisztériuma; $\mathrm{FADH}_{2}=$ flavin-adenin-dinukleotid; FIKP = Felsőoktatási Intézményi Kiválósági Program; $\mathrm{GO}=$ glioxál $;$ GOLD = glioxál-lizin dimer; GSH = glutation; $\mathrm{LDL}=($ low-density lipoprotein $)$ alacsony sưrúségú lipoprotein; $\mathrm{MGO}=$ metilglioxál $;$ MOLD = metilglioxál-lizin dimer; $\mathrm{NADH}=$ nikotinamid-adenin-dinukleotid; $\mathrm{NADPH}=($ nicotinamide adenine dinucleotide phosphate) nikotinamid-adenin-dinukleotid-foszfát; $\mathrm{NF} \kappa \mathrm{B}=$ (nuclear factor kappa-lightchain-enhancer of activated $\mathrm{B}$ cells) nukleáris faktor-kappa-B; NKFIH $=$ Nemzeti Kutatási, Fejlesztési és Innovációs Hivatal; $\mathrm{NKP}=$ Nemzeti Kiválósági Program; NO = nitrogén-monoxid; $\mathrm{PKC}=$ proteinkináz-C; RAGE $=$ (receptor of advanced glycation endproduct) késői glikációs végtermék receptora; ROS $=$ (reactive oxygen species) reaktívoxigén-származékok; SOD $=$ szuperoxid-dizmutáz; UPR $=$ (unfolded protein response) sérült fehérjeválasz
\end{abstract}

Nehéz a diabetesről, az általa okozott szövődményekről közhelyek nélkül írni. Természetesen sokkoló, hogy 2017-ben mintegy 451 millió embertársunkat érintette ez a probléma [1]. Szintén megdöbbentő, hogy ugyanebben az évben közel 5 millióan közülük a diabetes miatt haltak meg [2]. A száraz adatok mögött milliónyi olyan ember van, aki a mindennapjait a súlyos szövődmények miatt erôsen romlott minőségben éli. Az már régóta ismert, hogy a hyperglykaemia és a diabeteses szövődmények között meglehetősen szoros összefüggés áll fenn [3]. A diabeteses vascularis szövődmények és a hyperglykaemia között fennálló kapcsolatot a nagyobb mértékben keletkező késői glikációs végtermékek (AGE-k), valamint a fokozott oxidatív és karbonilstressz teremtheti meg [3]. Ezen kapcsolat pontos biokémiai ismerete lehetőséget teremthet annak a látszólagos anomáliának a megértésére, hogy egyes ritka, szórványos esetekben rosszabb anyagcserekontrollal rendelkező betegekben miért nem vagy csak kevesebb szövődmény alakul ki, mint jobb kontrollal rendelkező társaikban, illetve beavatkozási lehetőséget nyújthat mindannyiuk számára. Dolgozatunkban ezért kitérünk arra, hogy a karbonilstresszt csökkentő endogén dipeptid, a karnozin lebon- tását végző karnozinázok genetikai polimorfizmusa néhány ritka esetben miként okozhatja azok nagyobb aktivitását, így a szövődmények ellen védő karnozinmolekula alacsonyabb szintjét.

\section{Reaktív karbonilvegyületek képződése a szervezetben}

Reaktívoxigén-származékok (ROS) gyakorlatilag a szervezet valamennyi sejtjében keletkeznek. A fiziológiás mértékú ROS-képződésnek fontos szerepe van számos élettani folyamatban, különösképpen a jelátviteli útvonalakban [4]. A ROS képződése és a sejtek antioxidáns védelme közötti egyensúly megbomlásakor oxidatív stressz lép fel. Ez az állapot a biomolekulák oxidatív módosulását és károsodását okozhatja [5]. A hosszú távú oxidatív stressz és a módosított endogén makromolekulák felgyülemlése sejthalált [6], valamint az anyagcsere patológiás változásait válthatja ki [7].

A többszörösen telítetlen zsírsavak könnyen reakcióba lépnek a nagy reaktivitású ROS-kal, a hidroxilgyökkel, ami a lipidek peroxidációjához vezet [8]. A lipidperoxidáció következtében ún. reaktívlipid-aldehidek (más néven reaktívkarbonil-gyökök, például malondialdehid) képződnek, amelyek közül az $\alpha, \beta$-telítetlen aldehidek játsszák a legfontosabb szerepet. Legismertebb képviselőjük a 4-hidroxinonenál (4-HNE) [8].

A fehérjekarboniláció folyamatában [9] egy reaktívlipid-aldehid kovalensen kötődik bizonyos aminosavak oldalláncaihoz, a fehérjén szabad karbonilcsoportot eredményezve. A fehérjekarboniláció jellemző molekuláris mechanizmusa a Michael-addíció, amelynek során lizin, hisztidin vagy cisztein aminosavak funkciós csoportjaikkal nukleofil támadást indítanak az $\alpha, \beta$-telítetlen aldehidek 3 -as számú szénatomján $[10,11]$. A reaktívlipid-aldehidek alternatív módon, Schiff-bázis-képzéssel is reagálhatnak fehérjék primer aminocsoportjaival, ez azonban nem eredményez karbonilcsoportot [10].

A fehérjekarboniláció következtében intra- és intermolekuláris keresztkötések létesülnek [9], illetve számos enzimre aktiválóan/gátlóan hatva befolyásolja azok funkcióját [12]. A fehérjekarboniláció célmolekuláinak döntő része mitokondriális fehérje [9], ami nem csoda, hiszen a ROS 90\%-a mitokondriális eredetú, igaz, a reaktívlipid-aldehidek szabadon diffundálnak a membránokon keresztül, így a módosított fehérjék lokalizációja nem feltétlenül egyezik meg a ROS keletkezési helyével. A szignáltranszdukcióban részt vevő fehérjék módosítá- 
sán keresztül jelátviteli útvonalak is érintetté válhatnak a folyamatban: aktiválódásukkal például génexpressziós változás következhet be.

\section{Reaktívkarbonil-vegyület és AGE fokozott képződése diabetesben}

A hyperglykaemia következtében felpörgött citromsavciklusban fokozódik az elektrondonor NADH és $\mathrm{FADH}_{2}$ képződése. Ezáltal a mitokondriális elektrontranszferlánc is felgyorsul, ami a terminális oxidáció során szuperoxidgyök-anion megnövekedett termeléséhez, oxidatív stressz kialakulásához vezet [13].
A redukálócukrok, mint például a glükóz, nem enzimes módon reagálnak az aminosavak, lipidek és nukleinsavak aminocsoportjaival. Ezáltal a magas vércukorszint a késői glikációs végtermékek (advanced glycation endproducts, AGEs) képződését, felhalmozódását okozza. Az AGE-k glikált fehérjéból, lipoproteinekből és nukleinsavakból álló heterogén vegyületcsoport. Képződésük mértéke függ az időtől (lassú folyamat, így elsősorban a hosszú féléletidejü fehérjék érintettek), a monoszacharid koncentrációjától [14], valamint típusától [15].

Az AGE-k különböző reakcióutakon képződhetnek. A nem enzimes glikáció klasszikus, nem oxidatív útja Maillard-reakció néven is ismert. Elsőként a monosza-

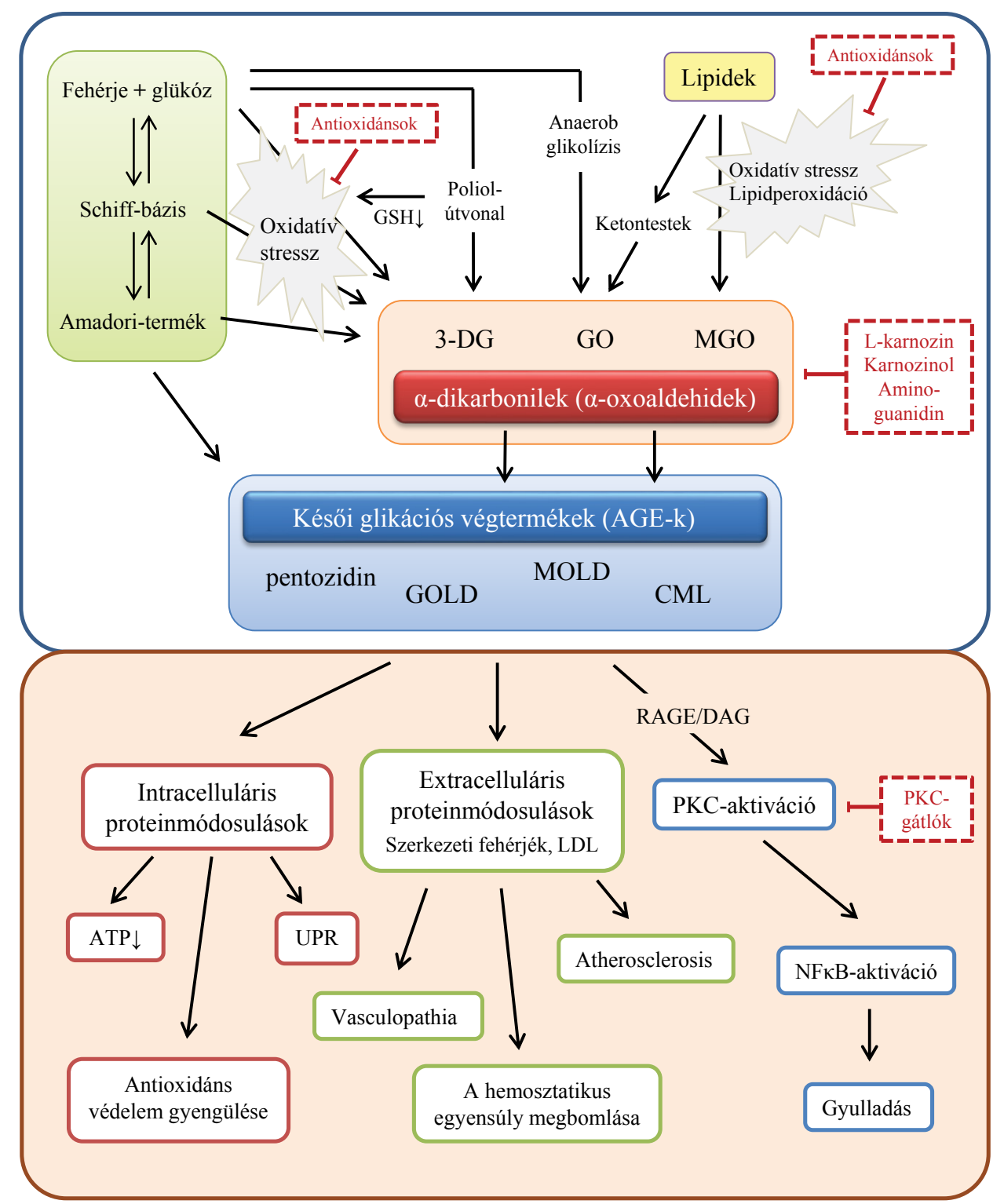

1. ábra $\quad$ Az AGE-k képződésének lehetséges útvonalai (fent) és az AGE-akkumuláció okozta patomechanizmusok (lent). A szaggatott vonallal ellátott keretek a beavatkozási lehetőségeket jelölik

3-DG = 3-deoxiglukozon; AGE = késői glikációs végtermék; ATP = adenozin-trifoszfát; $\mathrm{CML}=\mathrm{N}^{\varepsilon}$-[ $[$ karboximetil]-lizin; DAG $=$ diacil-glicerol; $\mathrm{GO}=$ glioxál; GOLD = glioxál-lizin dimer; GSH = glutation; $\mathrm{LDL}=$ alacsony súrúségú lipoprotein; $\mathrm{MGO}=$ metilglioxál; MOLD = metilglioxál-lizin dimer; $\mathrm{NF}_{k} \mathrm{~B}=$ nukleáris faktor-kappa-B; $\mathrm{PKC}=$ proteinkináz-C; RAGE = késői glikációs végtermék receptora; UPR = sérült fehérjeválasz 
charid és az aminocsoportok között az amidkötést tartalmazó, labilis Schiff-bázis jön létre, majd egy lassúbb izomerizáció következtében a stabil, de nem teljesen irreverzibilis szerkezetű, ketoaminkötést tartalmazó Amadori-termék keletkezik. Ezek további átalakulásokon mehetnek keresztül, a késői glikációs végtermékeket eredményezve [16].

Az AGE-k képződésében egyéb, hyperglykaemiában jellemző, nem oxidatív útvonalak is szerepet játszanak, mint például a poliolút, az anaerob glikolízis, illetve a ketontestképződés [13, 17].

A nem enzimes glikáció azonban oxidatív környezetben is végbemehet, ekkor a folyamatot glikoxidációnak nevezzük [16]: a glükóz autoxidációja [18], illetve a telítetlen zsírsavak lipidperoxidációja [19] is AGE-képződést eredményezhet.

Így a reaktívkarbonil-származék $\alpha$-oxoaldehidek vagy a-dikarbonilek - mint a glioxál, a metilglioxál vagy a 3-deoxiglukozon - kapcsolatot teremtenek az általuk kiváltott karbonilstressz és az AGE-képződés között [17] (1. ábra).

Az AGE-k igen nagy, heterogén vegyületcsoportot alkotnak, közülük a legismertebb glikoxidációs úton képződött molekulák a $\mathrm{N}^{\varepsilon}$-[karboximetil]-lizin (CML) és a pentozidin, illetve a nem oxidatív úton keletkezettek közül a glioxál-lizin dimer (GOLD) és a metilglioxál-lizin dimer (MOLD) [17].

Az AGE-k extracellulárisan sejtfelszíni receptorokhoz kötődnek, amely receptorok a ligand általi aktivációjuk downstream hatása alapján két csoportra oszthatók [14]. Az AGE-metabolizmusban (endocytosis, lebontás, eltávolítás) részt vevő receptorok prototípusa az AGERl: szerepet játszik a ROS-termelés gátlásában, továbbá az AGE-k ellen irányuló védekezőfolyamatokban [20]. Akut AGE-koncentráció-növekedés esetén az AGERl expressziójának fokozódását figyelték meg, de krónikus oxidatív stressz és tartósan magas AGE-koncentráció hatására (így diabetesben is) lecsökken az AGERl kifejeződése [21]. Az AGERl továbbá mérsékli a RAGE expresszióját és a RAGE-signalingot [21].

A RAGE a másik csoportba tartozó receptor: gyulladásos sejtválaszt indukál, hozzájárul a további ROS-termeléshez [22]. Az AGE-RAGE kapcsolat közremúködik a diabetes szövődményeinek kialakulásában [23]. Fontos megjegyeznünk, hogy a RAGE-gén egy bizonyos polimorfizmusa emelkedett kockázatot jelent a diabeteses nephropathia kialakulására 1-es típusú diabetes esetén [24], hozzájárulva a szövődmények genotípus okozta kevésbé kiszámítható fellépéséhez.

\section{A karbonilstressz jelentősége a szövődmények kialakulásában}

A szuperoxidgyök-anion hyperglykaemiában jelentkező fokozott termelése által kiváltott oxidatív stressz - a glioxidáción és a fehérjekarboniláción keresztül - kiemelt szerepet játszik a diabetes micro- és macrovascularis szövődményeinek kialakulásában [13].

Az AGE-akkumuláció, a karbonilstressz három különböző módon fejti ki hatását: az intracelluláris, valamint az extracelluláris fehérjemódosítások, továbbá a jelátviteli kaszkádok modulációján keresztül.

\section{Intracelluláris fehérjemódositások}

Az endoplasmás reticulum foldingot aktívan segítő fehérjéinek karbonilációja a hibásan tekeredett fehérjék akkumulációját okozza. Mindez kiválthatja a sérült fehérjeválaszt (unfolded protein response, UPR), akár apoptózishoz is vezethet [25].

A mitokondriális fehérjék nagy százalékban érintettek a fehérjekarbonilációban, ez az elektrontranszfer defektusát, következményes ATP-szintézis-csökkenést, valamint további ROS-produkciót okozhat [14].

Az antioxidáns védelemben részt vevő enzimek módosítása, inaktivációja tovább mélyíti az oxidatív stresszt. Ismert jelenség a SOD glikációja [18], feltételezhetően ennek köszönhetően erythrocytákban csökkent SODaktivitás mérhető 2-es típusú diabetesben [26]. A SODnak nagy szerepe van a diabeteses retinopathia és nephropathia kialakulásának megelőzésében [27].

Leírták a kataláz [15] és a glutation-reduktáz [28] enzimek glikációját is. Mindkét típusú diabetesben csökkent katalázaktivitást találtak erythrocytákban, illetve csökkent glutation-reduktáz- és glutation-peroxidáz-aktivitást észleltek 1-es típusú diabetesben [26].

\section{Extracelluláris proteinmódosulások}

Az extracelluláris térben létrejövő AGE-keresztkötések eredményeképpen a módosított szerkezeti fehérjék ellenállnak a hidrolízisnek, megakadályozva a szövet újraszervezését [14]. A kollagén, az elasztin és a laminin a kötőszövet főbb hosszú féléletidejű komponensei, így különösen érzékenyek az AGE-módosításokra [14]. Mindez a vasculopathia olyan különböző formáit eredményezi, mint pédául az érfalvastagodás vagy a csökkent érfalrugalmasság [29]. Ezen microvascularis elváltozások hozzájárulnak az adott szervekben a nephropathia, neuropathia, retinopathia kialakulásához.

A véralvadás elemei is érintettek a karbonilációban hemosztatikus abnormalitásokat okozva. Az oxidatív stressz kiváltotta thrombocytaaktiváció megnövekedett aggregációs hajlamhoz vezet, míg a glikált fibrinogén ellenállóbb a degradációval szemben, ami a fibrinolízis gyengülését eredményezi. Mindez a koagulációs aktivitás növekedésének irányába tolja el a hemosztatikus egyensúlyt [30].

A karbonilstressz hatása a lipoproteinekre is kiterjed: a kis sûrüségû lipoprotein (LDL) oxidálódásának következtében az LDL-receptorok nem veszik fel a keringésből. A makrofágok, bekebelezve az LDL-eket, habsejtekké alakulnak, és az érfalban lerakódva hozzájárulnak az atherosclerosis kialakulásához [31]. 


\section{Jelátviteli kaszkádok modulációja}

A proteinkináz-C ( $\mathrm{PKC})$ enzimcsalád transzkripciós faktorok, metabolikus enzimek és cytoskeletalis fehérjék múködését befolyásolja; a hyperglykaemia direkt módon a diacil-glicerolon keresztül vagy indirekt a RAGE-AGE kapcsolat eredményeképpen, illetve a poliolútvonalon át aktiválja a PKC-t [13].

A PKC indukciójának eredményeképpen a 'nuclear factor kappa-light-chain-enhancer of activated B cells' $\left(\mathrm{NF}_{\kappa} \mathrm{B}\right)$ transzkripciós faktor transzlokálódik a nucleusba [32], és génexpressziós reguláción keresztül lokálisan gyulladásos folyamatokat indukál. A folyamat eredményeképpen nő az érfal áteresztőképessége, angiogenezis indukálódik, atheroscleroticus laesiók alakulnak ki. A RAGE promóterében NFkB-kötő helyeket azonosítottak, így a folyamatban pozitív visszacsatolás is található: az $\mathrm{NF}_{\kappa} \mathrm{B}$ fokozza a RAGE expresszióját [26].

$\mathrm{Az}$ indukált PKC gátolja az endothelialis NO-szintázexpresszió inzulin okozta stimulációját is [13]. A szuperoxidgyök-anion a mitokondriumban NO-dal reagálva peroxinitritet képez, amely irreverzibilisen gátolja az elektrontranszferláncot és így az ATP-termelést [33]. Következésképpen hyperglykaemia esetén a fokozott ROS-termelés lecsökkenti a NO-szintet, amit a gátolt átíródású NO-szintáz nem tud kompenzálni. A NOszint-csökkenés vasoconstrictiót okoz az endothelsejtekben, továbbá a NO kieső antiproliferatív hatása miatt mindez az érfal megvastagodásához is vezet [34]. Az endothelin-1 aktivitásának növelése pedig további fokozott vasoconstrictióhoz vezet $[13,35]$.

A PKC-gátlók esetleges terápiás hatását számos tanulmányban vizsgálták. Sztreptozotocin indukálta diabeteses patkányokban hosszú távú PKCß-inhibitor-kezeléssel ígéretes eredményeket értek el diabeteses nephropathiában [36]. A humán kísérletek ruboxistaurin (PKCß-gátló) neuropathia esetén nem voltak sikeresek [27], azonban retinopathia és nephropathia esetén kimutatták a PKC $\beta$ izoforma szerepét, így ezen szövődmények mérséklésére ígéretes terápiás lehetőségnek tünik a ruboxistaurin [37].

Az AGE-k közvetlen hatása mellett a poliolútvonal is hozzájárul a diabeteses szövődmények kialakulásához, amit részben alátámaszt, hogy az útvonal két kulcsenzime jelen van a szövődmények által érintett szövetekben. A felgyülemlett glükózt a sejtekben az aldóz-reduktáz enzim szorbitollá alakítja, majd a szorbitol-dehidrogenáz katalizálta reakció fruktózt eredményez. A fruktózból fruktóz-3-foszfát, majd az AGE-képződés reaktív intermediere, a 3-DG keletkezik. Azon túl, hogy a poliolútvonal hozzájárul a további AGE-termeléshez, feltehetően az aldóz-reduktáz NADPH-igénye általi GSH-depléció és az így elmélyülő oxidatív stressz lehet felelős az útvonal káros hatásáért [13].

Sajnos aldóz-reduktáz inhibitorokkal gátolva a poliolútvonalat, a különböző in vivo vizsgálatok ellentmondásos eredményekre jutottak, így terápiás használhatóságuk egyelőre kérdéses [27].

\section{Terápiás lehetóségek: reaktívkarbonil-fogó molekulák}

A terápia terén igen nagy reményeket füztek az aminoguanidinhez, amely egy hidrazinszerü molekula, az $\alpha, \beta$-telítetlen aldehideket befogó molekulák prototípusa. Rendkívül gyorsan köti meg a karbonil- és dikarbonilvegyületeket (GO, MGO, 3-DG), ezzel megelőzve az AGE-formációt. Habár számos tanulmány bizonyította különböző állatmodelleken való sikerességét [38-40], a klinikai tesztek nem bizonyultak sikeresnek: a 15 éve publikált ACTION I-vizsgálat során (690, l-es típusú diabetesben szenvedő beteg nephropathia és retinopathia szövődményeivel) nem volt kimutatható szignifikáns javulás a nephropathia tekintetében [41]. Az ACTION II-kipróbálást (599, 2-es típusú diabeteses páciens vesebetegséggel) az External Safety Monitoring Committee javaslatára pedig a hatékonyság hiánya miatt és biztonsági okokra hivatkozva (jelentkező mellékhatások: gastrointestinalis tünetek, rendellenességek a májfunkciós teszteken, influenzaszerü tünetek) közel 20 évvel ezelött leállították [42].

$\mathrm{Az}$ aminoguanidin mellett nagy várakozás fogadta az endogén dipeptid L-karnozint (béta-alanil-L-hisztidin) is, amely szintén hatásosan fojtja el a karbonilstresszt: szelektíven képez stabil adduktot az $\alpha, \beta$-telítetlen aldehidekkel. Ez esetben is számos in vivo modellben született ígéretes eredmény [43], a humán alkalmazást azonban az emberekben jelen lévő (míg a rágcsálókból hiányzó) specifikus szérumhidrolázok (karnozinázok), az alacsony szérumstabilitás és a biológiai hasznosulás limitálta [44]. A karnozinnak a szövődmények megelőzésében játszott igen valószínú szerepére világít rá (a karnozint bontó) karnozináz-1 és -2 génjében (CNDPl és CNDP2) található polimorfizmus okozta megnövekedett karnozinázaktivitás és a diabeteses nephropathia kialakulása között kimutatott összefüggés [45, 46].

Ha a karnozin ilyen kiváló tulajdonságokkal rendelkezik, érdemes lenne úgy módosítani a molekulát, hogy az ellenálló legyen a karnozinázoknak, ugyanakkor megőrizze biológiai biztonságát és karbonilstresszt csökkentő hatását. Úgy tûnik, hogy a múlt év végén a molekula karboxilcsoportjának hidroxilcsoportra történő cseréjével sikerült elérni a kívánt hatást. Az új molekula, az ily módon racionális tervezéssel létrehozott karnozinol, igen szelektíven és nagy reaktivitással hatástalanította a reaktívkarbonil-származékokat, sőt a HNE, az MGO és az akrolein irányában reaktívabb, mint maga az L-karnozin, illetve mint az eddig vizsgált bármely karnozinszármazék. A karnozinol mind humán szérumban, mind patkány- és humán májkivonatban stabilnak bizonyult, ami egyértelmúen arra utal, hogy a molekulatervezés céljainak megfelelően valóban nem bontják a karnozinázok [44]. Mind in vitro, mind in vivo kísérletek alapján az L-karnozinhoz hasonló kiváló biztonsági profillal rendelkezik, megfelelően transzportálódik a bélcsatornából, így jó orális biológiai hasznosulással bír. Magas fruktóz- 
diétán tartott patkányok esetében a karnozinol dózisfüggô módon képes volt mérsékelni a diéta következtében kialakult szisztolés magas vérnyomást [44]. Megjegyzendő, hogy szintén dózisfüggő módon képes volt csökkenteni a szérum-AGE, illetve a gyulladásos citokinek szintjét. Fontos rámutatni, hogy az oxidatív és gyulladásos stressz mérséklésével párhuzamosan a metabolikus paraméterek is javultak, így dózisfüggő módon csökkent a szérum-triglicerid- és -koleszterinszint, illetve javult a glykaemiás kontroll, mérséklődött a magas fruktózdiéta kiváltotta hepatotoxicitas, illetve steatosis mértéke is [44]. Mind a szisztémás metabolikus, mind a szisztémás gyulladásos paraméterekben tapasztalt javulás együtt járt a plasma, a vese és a máj HNE-addukt szintjének csökkenésével [44].

A kifejlesztése óta eltelt rövid idő (mindössze fél év) nem tette lehetővé, hogy klinikai teszteken bizonyítson a molekula, azonban a fentiekben röviden összefoglalt kedvező sajátságai, az in vitro és in vivo eredmények alapján érdemes a klinikusnak is felfigyelni a karnozinolban rejlő lehetőségekre, nyomon követni a vele kapcsolatos híreket, eredményeket.

\section{Következtetés}

Lassan 100 év telt el az - orvostudomány egyik sikertörténetének tekintett - inzulin tisztítása, az első inzulinkezelés óta. Habár az inzulinkezelés megoldotta a diabetes akut problémáját, a hosszú távú szövődmények azóta is szedik áldozataikat; ezek leküzdése az inzulinkezeléshez hasonlatosan valódi áttörést jelentene. A diabeteses szövődmények és a hyperglykaemia közötti kapcsolat igazolt, hiszen a hyperglykaemia fokozott oxidatív és karbonilstresszel, nagyobb mértékü AGE-képződéssel jár együtt [2]. A jelen tanulmányban áttekintettük az AGE-k képződését, lehetséges szerepüket a szövődmények kialakulásában, és beszámoltunk a terápiás beavatkozás egy lehetséges új módjáról.

Az AGE-k képződésében nem oxidatív (Maillard-reakció, poliolút, anaerob glikolízis, ketontestképződés $[13,17]$ ) és oxidatív (a glükóz autoxidációja [18], a telítetlen zsírsavak lipidperoxidációja [19]) folyamatok egyaránt közrejátszanak, kapcsolatot teremtve a karbonilstressz és az AGE-keletkezés között [17]. Az AGEképződés legpotensebb támadási pontja így az $\alpha, \beta$-telítetlen aldehidek befogása lehet. Sajnálatos módon az $\alpha, \beta$-telítetlen aldehideket befogó molekulák prototípusát jelentő aminoguanidin, bár különböző állatmodelleken sikeresnek bizonyult, a klinikai teszteken nem bizonyított, sőt a hatékonyság hiánya és biztonsági okok miatt a vele kapcsolatos klinikai vizsgálatokat közel 20 évvel ezelőtt leállították [42]. Az aminoguanidin mellett nagy várakozás fogadta az endogén dipeptid L-karnozint (béta-alanil-L-hisztidin), amely szintén hatásosan csökkenti a karbonilstresszt: szelektíven képez stabil adduktot az $\alpha, \beta$-telítetlen aldehidekkel. Ez esetben is számos in vivo modellben született ígéretes eredmény [43], azon- ban a humán alkalmazást az emberekben jelen lévő (míg a rágcsálókból hiányzó) specifikus szérumhidrolázok (karnozinázok), az alacsony szérumstabilitás és a biológiai hasznosulás limitálta [44]. Úgy tûnik, hogy a múlt év végén a molekula karboxilcsoportjának hidroxilcsoportra történő cseréjével sikerült elérni, hogy ellenálló legyen a karnozinázoknak, ugyanakkor megőrizze biológiai biztonságát és karbonilstresszt csökkentő hatását. Bár a kifejlesztése óta eltelt mindössze fél év nem tette lehetővé, hogy klinikai teszteken bizonyítson, a molekulával kapcsolatban elért in vitro és in vivo eredmények alapján érdemes a klinikusnak is nyomon követni a vele kapcsolatos híreket, eredményeket.

Anyagi támogatás: A kézirat elkészítését az NKFIH K123752, KH129593, 2018-1.2.1-NKP-2018-00005 pályázatai, illetve az EMMI BME-Biotechnológia FIKP pályázata támogatta.

Szerzői munkamegosztás: M.-M. K.: Az irodalomkutatás elvégzése, a kézirat megírása. Sz. A.: A kézirat koncepciója, a bevezetés és a következtetés megírása, a kézirat lektorálása, szakmai véleményezése. A cikk végleges változatát mindkét szerző elolvasta és jóváhagyta.

Érdekeltségek: A szerzőknek nincsenek érdekeltségeik.

\section{Irodalom}

[1] International Diabetes Federation. IDF Diabetes Atlas, 8th edn. International Diabetes Federation, Brussels, 2017. Available from: http://www.diabetesatlas.org [accessed: June 1, 2019].

[2] Bellier J, Nokin MJ, Lardé E, et al. Methylglyoxal, a potent inducer of AGEs, connects between diabetes and cancer. Diabetes Res Clin Pract. 2019; 148: 200-211.

[3] Yamagishi S, Maeda S, Matsui T, et al. Role of advanced glycation end products (AGEs) and oxidative stress in vascular complications in diabetes. Biochim Biophys Acta 2012; 1820: 663671.

[4] Nemoto S, Takeda K, Yu ZX, et al. Role for mitochondrial oxidants as regulators of cellular metabolism. Mol Cell Biol. 2000; 20: 7311-7318.

[5] Sies, H. Biochemistry of oxidative stress. Angew Chem Int. 1986; 25: 1058-1071.

[6] Dalleau S, Baradat M, Guéraud F, et al. Cell death and diseases related to oxidative stress: 4-hydroxynonenal (HNE) in the balance. Cell Death Differ. 2013; 20: 1615-1630.

[7] Furukawa S, Fujita T, Shimabukuro M, et al. Increased oxidative stress in obesity and its impact on metabolic syndrome. J Clin Invest. 2004; 114: 1752-1761.

[8] Esterbauer H, Schaur RJ, Zollner H. Chemistry and biochemistry of 4-hydroxynonenal, malonaldehyde and related aldehydes. Free Radic Biol Med. 1991; 11: 81-128.

[9] Curtis JM, Hahn WS, Long EK, et al. Protein carbonylation and metabolic control systems. Trends Endocrinol Metab. 2012; 23: 399-406.

[10] Schaur RJ. Basic aspects of the biochemical reactivity of 4-hydroxynonenal. Mol Aspects Med. 2003; 24; 149-159.

[11] Poli G, Biasi F, Leonarduzzi G. 4-Hydroxynonenal-protein adducts: a reliable biomarker of lipid oxidation in liver diseases. Mol Aspects Med. 2008; 29: 67-71. 
[12] Aldini G, Dalle-Donne I, Facino RM, et al. Intervention strategies to inhibit protein carbonylation by lipoxidation-derived reactive carbonyls. Med Res Rev. 2007; 27: 817-868.

[13] Brownlee, M. Biochemistry and molecular cell biology of diabetic complications. Nature 2001; 414: 813-820.

[14] Fishman SL, Sonmez H, Basman C, et al. The role of advanced glycation end-products in the development of coronary artery disease in patients with and without diabetes mellitus: a review. Mol Med. 2018; 24: 59.

[15] Yan H, Harding JJ. Glycation-induced inactivation and loss of antigenicity of catalase and superoxide dismutase. Biochem J. 1997; 328: 599-605.

[16] Tessier FJ. The Maillard reaction in the human body. The main discoveries and factors that affect glycation. Pathol Biol. 2010; 58: 214-219.

[17] Turk Z. Glycotoxines, carbonyl stress and relevance to diabetes and its complications. Physiol Res. 2010; 59: 147-156.

[18] Wells-Knecht KJ, Zyzak DV, Litchfield JE, et al. Mechanism of autoxidative glycosylation: identification of glyoxal and arabinose as intermediates in the autoxidative modification of proteins by glucose. Biochemistry 1995; 34: 3702-3709.

[19] Fu MX, Requena JR, Jenkins AJ, et al. The advanced glycation end product, $\mathrm{N}^{\varepsilon}$-(carboxymethyl)lysine, is a product of both lipid peroxidation and glycoxidation reactions. J Biol Chem. 1996; 271: 9982-9986.

[20] Lu C, He JC, Cai W, et al. Advanced glycation endproduct (AGE) receptor 1 is a negative regulator of the inflammatory response to AGE in mesangial cells. Proc Natl Acad Sci USA 2004; 101: 11767-11772.

[21] Vlassara H, Uribarri J. Advanced glycation end products (AGE) and diabetes: cause, effect, or both? Curr Diab Rep. 2014; 14: 453.

[22] Coughlan MT, Thorburn DR, Penfold SA, et al. RAGE-induced cytosolic ROS promote mitochondrial superoxide generation in diabetes. J Am Soc Nephrol. 2009; 20: 742-752.

[23] Goldin A, Beckman JA, Schmidt AM, et al. Advanced glycation end products: sparking the development of diabetic vascular injury. Circulation 2006; 114: 597-605.

[24] Prevost G, Fajardy I, Besmond C, et al. Polymorphisms of the receptor of advanced glycation endproducts (RAGE) and the development of nephropathy in type 1 diabetic patients. Diabetes Metab. 2005; 31: 35-39.

[25] Adamopoulos C, Farmaki E, Spilioti E, et al. Advanced glycation end-products induce endoplasmic reticulum stress in human aortic endothelial cells. Clin Chem Lab Med. 2014; 52: 151-160.

[26] Merzouk S, Hichami A, Madani S, et al. Antioxidant status and levels of different vitamins determined by high performance liquid chromatography in diabetic subjects with multiple complications. Gen Physiol Biophys. 2003; 22: 15-27.

[27] Sztanek F, M Molnár Á, Balogh Z. The role of oxidative stress in the development of diabetic neuropathy. [Az oxidatív stressz szerepe a diabeteses neuropathia kialakulásában.] Orv Hetil. 2016; 157: 1939-1946. [Hungarian]

[28] Morgan PE, Dean RT, Davies MJ. Inactivation of cellular enzymes by carbonyls and protein-bound glycation/glycoxidation products. Arch Biochem Biophys. 2002; 403: 259-269.

[29] Aronson D. Cross-linking of glycated collagen in the pathogenesis of arterial and myocardial stiffening of aging and diabetes. J Hypertens. 2003; 21: 3-12.
[30] Takenaka K, Yamagishi S, Matsui T, et al. Role of advanced glycation end products (AGEs) in thrombogenic abnormalities in diabetes. Curr Neurovasc Res. 2006; 3: 73-77.

[31] Zieman SJ, Kass DA. Advanced glycation endproduct crosslinking in the cardiovascular system: potential therapeutic target for cardiovascular disease. Drugs 2004; 64: 459-470.

[32] Yerneni KK, Bai W, Khan BV, et al. Hyperglycemia-induced activation of nuclear transcription factor $\mathrm{kB}$ in vascular smooth muscle cells. Diabetes 1999; 48: 855-864.

[33] Ghafourifar P, Bringold U, Klein SD, et al. Mitochondrial nitric oxide synthase, oxidative stress and apoptosis. Biol Signals Recept. 2001; 10: 57-65.

[34] Shakher J, Stevens MJ. Update on the management of diabetic polyneuropathies. Diabetes Metab Syndr Obes. 2011; 4: 289305.

[35] Bierhaus A, Hofmann MA, Ziegler R, et al. AGEs and their interaction with AGE-receptors in vascular disease and diabetes mellitus. I. The AGE concept. Cardiovasc Res. 1998; 37: 586-600.

[36] Koya D, Haneda M, Nakagawa H, et al. Amelioration of accelerated diabetic mesangial expansion by treatment with a PKC $\beta$ inhibitor in diabetic $\mathrm{db} / \mathrm{db}$ mice, a rodent model for type 2 diabetes. FASEB J. 2000; 14: 439-447.

[37] Das Evcimen N, King GL. The role of protein kinase C activation and the vascular complications of diabetes. Pharmacol Res. 2007; 55: 498-510.

[38] Kern TS, Engerman RL. Pharmacological inhibition of diabetic retinopathy: aminoguanidine and aspirin. Diabetes 2001; 50: 1636-1642.

[39] Forbes JM, Yee LT, Thallas V, et al. Advanced glycation end product interventions reduce diabetes-accelerated atherosclerosis. Diabetes 2004; 53: 1813-1823.

[40] Stadler K, Jenei V, Somogyi A, et al. Beneficial effects of aminoguanidine on the cardiovascular system of diabetic rats. Diabetes Metab Res Rev. 2005; 21: 189-196

[41] Bolton WK, Cattran DC, Williams ME, et al., for the ACTION I Investigator Group. Randomized trial of an inhibitor of formation of advanced glycation end products in diabetic nephropathy. Am J Nephrol. 2004; 24: 32-40.

[42] Freedman BI, Wuerth JP, Cartwright K, et al. Design and baseline characteristics for the aminoguanidine clinical trial in overt Type 2 diabetic nephropathy (ACTION II). Control Clin Trials 1999; 20: 493-510.

[43] Boldyrev AA, Aldini G, Derave W. Physiology and pathophysiology of carnosine. Physiol Rev. 2013; 93: 1803-1845.

[44] Anderson EJ, Vistoli G, Katunga LA, et al. A carnosine analog mitigates metabolic disorders of obesity by reducing carbonyl stress. J Clin Invest. 2018; 128: 5280-5293.

[45] Janssen B, Hohenadel D, Brinkkoetter P, et al. Carnosine as a protective factor in diabetic nephropathy: association with a leucine repeat of the carnosinase gene CNDP1. Diabetes 2005; 54 : $2320-2327$.

[46] Ahluwalia TS, Lindholm E, Groop LC. Common variants in CNDP1 and CNDP2, and risk of nephropathy in type 2 diabetes. Diabetologia 2011; 54: 2295-2302.

(Szarka András dr., Budapest, Pf. 260, 1444 e-mail: szarka.andras@med.semmelweis-univ.hu)

A cikk a Creative Commons Attribution 4.0 International License (https://creativecommons.org/licenses/by/4.0/) feltételei szerint publikált Open Access közlemény, melynek szellemében a cikk bármilyen médiumban szabadon felhasználható, megosztható és újraközölhetö, feltéve, hogy az eredeti szerző és a közlés helye, illetve a CC License linkje és az esetlegesen végrehajtott módositások feltüntetésre kerülnek. (SID_1) 